\title{
Emerson and Skepticism
}

A Reading of "Friendship"

\section{Russell B. Goodman}

\section{(2) OpenEdition \\ 1 Journals}

Electronic version

URL: http://journals.openedition.org/ejpap/891

DOI: 10.4000/ejpap.891

ISSN: 2036-4091

\section{Publisher}

Associazione Pragma

\section{Electronic reference}

Russell B. Goodman, « Emerson and Skepticism », European Journal of Pragmatism and American Philosophy [Online], II-2 | 2010, Online since 21 December 2010, connection on 07 May 2019. URL http://journals.openedition.org/ejpap/891 ; DOI : 10.4000/ejpap.891

This text was automatically generated on 7 May 2019.

\section{(c) $(1)$}

Author retains copyright and grants the European Journal of Pragmatism and American Philosophy right of first publication with the work simultaneously licensed under a Creative Commons AttributionNonCommercial-NoDerivatives 4.0 International License. 


\title{
Emerson and Skepticism
}

\author{
A Reading of "Friendship"
}

\author{
Russell B. Goodman
}

1 My consideration of Emerson's "Friendship" essay is part of a broader project of trying to make sense of Emerson's thought as a whole by delineating paths of coherence through it. These paths fall into two kinds: the consistent enunciation of a view or "master-tone" from essay to essay, and the internal linkage among these views. ${ }^{1}$ For example, the notion of process or flux finds its way into all Emerson's essays, and plays a central role in several of his greatest. Process is more than a subject for continuing discussion in various essays, however, for it is internally linked to many of Emerson's most important claims: that we must learn to skate over the surfaces of life, that all ethical forms are "initial," that language is most effectively used for "conveyance" rather than for "homestead," that "all things good are on the highway."

2 While thinking about these paths of coherence among Emerson's essays, I have at the same time been attending to the ways Emerson's individual essays work: to their order, progression, argument, points of view. ${ }^{2}$ In this paper, I want to consider the "Friendship" essay in all these ways: to chart the course of its argument, to delineate its connections with other writings of Emerson's, and to explore the conceptual connections between friendship and such other Emersonian concepts as self-reliance.

3 I begin not with the "Friendship" essay itself, but with strands of Emerson's discussion of friendship that we find in some of his other essays. In "Spiritual Laws," a companion essay to "Friendship" in the Essays, First Series, Emerson describes the way friendships begin. They have nothing to do with effort, worldly accomplishments, or physical beauty, he asserts, but are rather matters of attraction or affinity. When "all is done," Emerson writes, "a person of related mind, a brother or sister by nature, comes to us so softly and easily, so nearly and intimately, as if it were the blood in our proper veins, that we feel as if some one was gone, instead of another having come: we are utterly relieved and refreshed: it is a sort of joyful solitude" (CW2: 87). ${ }^{3}$ Friendships, like much of the best in life as Emerson sees it, are spontaneous and unforced.

4 Friendship appears in a rather different context in "The Divinity School Address," where Emerson complains that Christianity has lost the essential friendliness of Jesus's message, 
so that "the friend of man is made the injurer of man." The language "that describes Christ to Europe and America," Emerson complains,

is not the style of friendship and enthusiasm to a good and noble heart, but is appropriated and formal, - paints a demigod, as the Orientals or the Greeks would describe Osiris or Apollo [...]. The time is coming when all men will see, that the gift of God to the soul is not a vaunting, overpowering, excluding sanctity, but a sweet, natural goodness, a goodness like thine and mine, and that so invites thine and mine to be and to grow. (CW1: 82-3)

5 Jesus is the divine friend of divine men and women, Emerson holds. He is a god who is not foreign but right at hand - as close as our friends in our best moments together, when we are invited "to be and to grow." The friendly message of Jesus, Emerson is saying, has been usurped, or as we would now say, hijacked - transformed into a message of fear, alienation, and hostility.

6 If friendship is central to Emerson's conception of Christianity, it is equally central to his conception of art, specifically to painting. Describing his first experiences with the great paintings of Europe in the essay "Art," Emerson writes that he "fancied the great pictures would be great strangers; some surprising combination of color and form; a foreign wonder." Instead, he found the paintings "famililar and sincere, [...] the plain you and me I knew so well, - had left at home in so many conversations" (CW2: 214). He found Raphael's Transfiguration, in particular, was "familiar [...] as if one should meet a friend" (CW2: 215).

But Emerson strikes another note here in "Art" that will be crucial to my reading of "Friendship" - for it is a skeptical note. Continuing the argument we have been examining, he takes one of his characteristic dialectical turns, signaled by a new paragraph beginning with the word "yet":

Yet when we have said all our fine things about the arts, we must end with a frank confession, that the arts, as we know them, are but initial. Our best praise is given to what they aimed at and promised, not to the actual result. He has conceived meanly of the resources of man, who believes that the best age of production is past. The real value of the Iliad, or the Transfiguration, is as signs of power; billows or ripples they are of the stream of tendency; tokens of the everlasting effort to produce [...]. There is higher work for Art than the arts. They are abortive births of an imperfect or vitiated instinct. (CW2: 215)

Emerson's terms for the arts he has experienced are derogatory: they are said to be "abortive births," and to give only a "mean" idea of human resources and creativity. Yet Emerson also asserts their value as "signs of power," as inspirations or reminders of something "aimed at and promised." He turns against the great European painting that he has just praised because of its distance from the ideal, just as he turns from even the best books when he has his own work to do. In a similar manner and for similar reasons, he turns from his friends.

9 The final essay I wish to cite before considering "Friendship" is "Experience," a complex assessment of human life in the context of the death of Emerson's son Waldo. "Experience" presents what Cavell has called an "epistemology of moods," ${ }^{4}$ according to which life is a succession of different and sometimes irreconcilable perspectives on or appreciations of things. In the passage I wish to consider, Emerson considers the different books with which he has had intense relationships:

Once I took such delight in Montaigne that I thought I should not need any other book; before that, in Shakespeare; then in Plutarch; then in Plotinus; at one time in Bacon; afterwards in Goethe; even in Bettine; but now I turn the pages of either of 
them languidly, whilst I still cherish their genius. So with pictures; each will bear an emphasis of attention once, which it cannot retain, though we fain would continue to be pleased in that manner. How strongly I have felt of pictures, that when you have seen one well, you must take your leave of it; you shall never see it again [...]. The reason of the pain this discovery causes us (and we make it late in respect to works of art and intellect), is the plaint of tragedy which murmurs from it in regard to persons, to friendship and love. (CW3: 33)

This passage from "Experience" brings friendship into alignment with a tragic theme in Emerson's thought that is often overlooked. Although we may still "cherish the genius" of the books and people we are no longer in touch with, Emerson is saying that we lose some- thing too - and that this loss is both painful and inescapable, hence tragic. We must take our leave of pictures, we must take our leave of friends, we must take our leave of books. These things that "you shall never see [...] again" are the flip side - the less pleasant face - of the surprises and flashing insights that Emerson characteristically seeks and records.

Emerson's idea that our human lives with others are disappointing chimes with Stanley Cavell's discussion of lived skepticism in The Claim of Reason. Our skepticism about others, Cavell asserts, is not an academic exercise, but as common as the jealousy of Othello, the blindness of Lear, the disappointment we feel with a conversation in which we have not expressed ourselves adequately. Cavell conceives of such lived skepticism not only as being unsure of others (as Othello is of Desdemona), but as rooted in a deep disappointment with even our best cases of knowing - as if, he writes, "we have, or have lost, some picture of what knowing another, or being known by another, would really come - a harmony, a concord, a union, a transparence, a governance, a power - against which our actual successes at knowing, and being known, are poor things." ${ }^{5}$

Emerson's critique is not directed at our best cases of friendship, whose satisfaction and promise he credits, but at friendships that fail to deliver on their initial promise. When he is in a glum mood about his life with his friends, he will say, as he does in one of the darker moments of the essay to which we will shortly turn: "Friendship, like the immortality of the soul, is too good to be believed" (CW2: 116). Emerson doesn't quite believe in his friends (he neither names nor refers to a particular friend in his essay), but he seeks and for some hours has found friendship. Cavell's work on "skepticism about other minds," centers on the question of our own responsibility - Lear's responsibility, Othello's responsibility - for failing to know others. Emerson's focus is different, not on our failures to acknowledge others but our failures to ask the best of both others and ourselves. I take from Cavell both the idea that skepticism is lived out in our lives with others, and a set of questions: whether skepticism is inescapable and whether it reveals something about our condition; whether it is to be accommodated, yielded to, overcome, or refuted. To put my cards on the table, I think Emerson shows us that a kind of lived skepticism concerning others is a feature of our lives, but that the accomplishments of friendship are too; and that in its powerful effect on us, friendship instills the hope for something better than the best friend we have.

Emerson's essay on "Friendship" begins in an unexpected place: with people "whom we scarcely speak to," or whom we merely "see in the street." We "warmly rejoice to be with" them, Emerson asserts. But what kind of being with is this? Emerson seems to be talking about a sense of human community and even love, which we feel even when there is no sign that it is reciprocated. No particular friend or relationship is singled out in Emerson's statement that the "whole human family is bathed with an element of love like 
a fine ether" (113). The tone is sanguine, but the reader is left to wonder where in this picture is the friendship of one person for another. ${ }^{6}$

The second paragraph continues with the idea of a generalized feeling of love and companionship, what Emerson calls "emotions of benevolence and complacency which are felt towards others." There is a hierarchy of such emotions, he now asserts, from "the lowest degree of good will," which seems to be Emerson's subject in these opening paragraphs, to "the highest degree of passionate love" (CW2: 113) - something he never quite manages to discuss in the essay.

In the third paragraph Emerson moves from these somewhat abstract and generalized remarks to a specific type of experience: our anticipation of the arrival in our house of a "commended stranger." What is this "stranger" doing in an essay on "Friendship?" one might ask. The stranger seems to stand for the possibilities of an ideal friendship, a friendship that we seek but do not have. In this way the commended stranger "stands for humanity," as Emerson puts it. Emerson asserts of the stranger that "He is what we wish" (CW2: 114), implying that we seek the stranger's company because he will give or inspire in us something we now lack, what he calls in "History" our "unattained but attainable self" (CW2: 5). Continuing his generic story of the arrival of the stranger, Emerson writes that the "house is dusted" and among its residents the stranger's "arrival almost brings fear to the good hearts that would welcome him" (CW2: 113). After all the preparation and anticipation the stranger's visit at first goes very well. We speak better than we are accustomed to, so that "our own kinsfolk and acquaintance [...] feel a lively surprise at our unusual powers." However, as the visit continues, the stranger turns out to be not as commendable as we had supposed, and the friend we had sought something still to be wished for. For the stranger begins "to intrude his partialities, his definitions, his defects, into the conversation," and then:

it is all over. He has heard the first, the last and the best, he will ever hear from us [...]. Vulgarity, ignorance, misapprehension, are old acquaintances. Now, when he comes, he may get the order, the dress, and the dinner, - but the throbbing of the heart, and the communications of the soul, no more. (CW2: 114)

What does this have to say about friendship? Not much, it might seem. There is no friend here, but mostly vulgar "old acquaintances" who don't show us the best of themselves and who do not elicit the best in us. It is this normal condition that we had hoped to escape and for a while did escape, with the commended stranger. The stranger awakens our always present desire for "the throbbing of the heart and the communications of the soul," for a humanity of the future. But he also disappoints us.

Emerson's little drama is a paradigm of lived skepticism in the following sense: it shows that our doubts about friendship are justified by the course of our experience. The stranger's arrival excites us with the hope of genius - his and ours - and he seems for some moments to be the ideal we seek. Emerson generalizes the point in "Experience" not just to commended strangers but to our friends. Our friends, he writes, "appear to us as representatives of certain ideas" (CW3: 251), but there is "an optical illusion" about them. Each turns out to have boundaries that are never passed, so that what seemed spontaneous and lively "in the year, in the lifetime, [...] turns out to be a certain uniform tune which the revolving barrel of the music-box must play" (CW3: 249). Emerson's "Friendship" essay is a meditation or set of variations on this theme of hope and disappointment in our lives with others. His initial drama includes several moods: the "throbbing heart" of anticipation, and the "fear" of the meeting with the stranger, the 
expansive elation in the beginnings of conversation when our own powers surprise those who know us, the mood of disappointment and resignation as we return from elated conversation to become once again the "dumb devil" who greets tedious old acquaintances. If, as Emerson says in "Experience," our life is "a train of moods like a string of beads" each showing "only what lies in its focus," then Emerson's friendship essay records the moods of our lives with others.

Let us return now to the course of Emerson's essay. As if beginning afresh, Emerson moves in paragraphs four and five to a discussion of the pleasures and advantages of friendship, which he now describes as "an encounter of two, in a thought, in a feeling" (CW2: 114). Yet amidst this praise for the overcoming of the boundaries between individuals comes the suggestion that those boundaries remain: "I chide society, I embrace solitude, and yet I am not so ungrateful as not to see the wise, the lovely, and the noble-minded as from time to time they pass my gate." This is an image of friendship, or perhaps just admiration, at a distance, and recalls the opening paragraph's cool pleasure in the people to whom one does not speak.

The sixth paragraph returns to the impending visit of a stranger, but now (as if in a new key) in the first person singular rather than the first person plural. "A new person is to me a great event," Emerson confesses, "and hinders me from sleep." Again he strikes a skeptical note: "I have often had fine fancies about persons which have given me delicious hours; but the joy ends in the day: it yields no fruit" (CW2: 115). Here it is not a disappointment with our criteria as such that is at issue, but a disappointment that reasonable criteria of friendship - which have been met in our best moments with our friends - are not met by this new visitor. Emerson oscillates between an appreciation of and skepticism about his friend: "I must feel pride in my friend's accomplishments as if they were mine," he states; but also: "We overestimate the conscience of our friend" (CW2: 115). Do we idolize our friends and they us, or do we accurately read each other's reality and promise?

Emerson begins the lengthy seventh paragraph with a series of skeptical observations and conclusions about belief and knowledge:

Friendship, like the immortality of the soul, is too good to be believed. The lover, beholding his maiden, half knows that she is not verily that which he worships; and in the golden hour of friendship we are surprised with shades of suspicion and unbelief. (CW2: 116)

21 In Emerson's other essays, surprises bring joy and expansion, a new and fuller perspective on life. Here however, we are surprised to find that our friend is more limited than we thought, that we project virtues onto her that are not really there. Rather than an underlying, living unity, Emerson now holds up "an Egyptian skull at our banquet" "an infinite remoteness" between persons.

From that remoteness Emerson turns to himself, to the self-reliant thought that a "man who stands united with his thought conceives magnificently of himself." Even if I do not fully feel my own wealth, he adds, "I cannot choose but rely on my own poverty, more than on your wealth." The friend, he continues, is not "Being," not "my soul," but only "a picture or effigy." And this brings Emerson to a thought that he elaborates throughout the essay: that our friends are for us to grow with and use, rather than components of a stable, unchanging relationship. The soul "puts forth friends," he writes, "as the tree puts forth leaves, and presently, by the germination of new buds, extrudes the old leaf" (CW2: 
116). Our friends, the metaphor says, are forms of our growth, but they are not essential to us. They are abandoned for new friends, new shoots and leaves.

The soul's growth, as Emerson sees it, is an alternation between states of society and solitude, each of which induces the opposite. "The soul environs itself with friends," he continues,

that it may into a grander self-acquaintance or solitude; and it goes alone, for a season, that it may exalt its conversation or society. This method betrays itself along the whole history of our personal relations. The instinct of affection revives the hope of union with our mates, and the returning sense of insulation recalls us from the chase. Thus every man passes his life in the search after friendship [...]. (CW2: 117)

Emerson's "instinct of affection" takes the form of a sample letter he writes to each new candidate for his friendship. The letter is couched in terms of certainty and doubt: the letter writer is not "sure" of his friend, cannot "presume in thee a perfect intelligence of me," but acknowledges that the desire for knowledge of and by the friend is "a delicious torment."

If Emerson turns against an easy acceptance of what passes for friendship, he also begins to turn against skepticism about friendship at the beginning of the ninth paragraph, a turn again announced by the word "yet": "Yet these uneasy pleasures and fine pains are for curiosity and not for life. They are not to be indulged." Life, Emerson is saying, offers us possibilities, glimpses, and hours of something better, and our doubts and disappointments should not deflect us from pursuing and appreciating them. We should not aim at "a swift and petty benefit" from our friends, but have the patience to allow them to be themselves. But after this pragmatic counsel of patience, the paragraph gravitates away from the possibilities of friendship back to a dire portrayal of society:

Almost all people descend to meet. All association must be a compromise, and, what is worst, the very flower and aroma of the flower of each of the beautiful natures disappears as they approach each other. What a perpetual disappointment is actual society, even of the virtuous and gifted! (CW2: 117)

But as if paragraph nine introduces a theme that is then taken up more strongly in paragraphs eleven and twelve, Emerson now turns toward the claim that ideal friendship is also "real," something found, however impermanently, in our experience. "I do not wish to treat friendships daintily," Emerson states, "but with roughest courage. When [friendships] are real, they are not glass threads or frostwork, but the solidest thing we know" (CW2: 118-9). Skepticism recedes as Emerson advances the epistemological claim that we know our friends, at least as well as anything else we know. Reprising themes of his opening paragraph, he speaks of the "sweet sincerity of joy and peace, which I draw from this alliance with my brother's soul [...]. Happy is the house that shelters a friend!"

Midway in the immense thirteenth paragraph, Emerson develops a conceptual analysis of friendship, as composed of Truth or Sincerity on the one hand, and Tenderness on the other (CW2: 120). Sincerity is a noble virtue, a "luxury," he states, "allowed, like diadems and authority, only to the highest rank, that being permitted to speak truth, as having none above it to court or conform unto" (CW2: 119). Sincerity resembles the straight talk and honest judgments of the "nonchalant boys, [...] sure of their dinner" in "SelfReliance," who "would disdain as much as a lord to do or say aught to conciliate one" (CW 2: 29). 
merson writes in "Self-Reliance" that "we are afraid of truth, afraid of fortune, afraid of death, and afraid of each other" (CW2: 43). In the "Friendship" essay this fear is depicted as insincerity: "We parry and fend the approach of our fellow man by compliments, by gossip, by amusements, by affairs" (CW 2: 119). For their part, our fellow men and women avoid the little we have to say or give by requiring that we humor them: each person, Emerson complains, "has some fame, some talent, some whim of religion or philanthropy in his head that is not to be questioned, and which spoils all conversation with him" (CW 2: 120). With a real friend, in contrast, one may be perfectly sincere, as one is with oneself. The friend is thus "a sort of paradox in nature," Emerson argues, because although a) "every man alone is sincere," and b) "at the entrance of a second person, hypocrisy begins," c) the true friend is an other with whom I may be as sincere as I am with myself. Emerson gives this paradox a metaphysical slant, and recalls the "idealism" that runs as a leitmotiv through his writing, as he ends the paragraph. He states:

I who alone am, I who see nothing in nature whose existence I can affirm with equal evidence to my own, behold now the semblance of my being in all its height, variety and curiosity, reiterated in a foreign form; so that a friend may well be reckoned the masterpiece of nature. (CW2: 120)

This is one of many moments in Emerson's texts where along with his confrontation of an essential self, he also finds an other - sometimes in nature, sometimes in the words of a poet, sometimes, as here, in a friend. The setting of the encounter with the ideal friend is one of pleasure and spectacle. As Emerson puts it in one of his seeming knockoff lines: "My friend gives me entertainment without requiring any stipulation on my part" (CW2: 120 ).

31 Emerson has distinguished two elements of friendship: sincerity and tenderness. In paragraph fourteen, he addresses tenderness, beginning with the tender anxiety we feel in the face of another person to whom we are drawn: "we can scarce believe that so much character can subsist in another as to draw us by love." But he undercuts this tenderness when he states: "I [...] tender myself least to him to whom I am the most devoted" (CW2: 120). The lesson seems to be: devotion yes, tenderness not so much. Emerson's critique (but not abandonment) of tenderness relies on the previous paragraph's discussion of sincerity and self-reliance. An excess of tenderness or a false idea of tenderness humoring someone, or following someone's stipulations - is the death of friendship, precisely because it conflicts with following one's own path.

Emerson thus sketches a reformed tenderness, blending "the municipal virtues of justice, punctuality, fidelity and pity" with a dose of the extraordinary or new. Friendship is to "dignify to each other the daily needs and offices" of our lives, but it should avoid degenerating into "something usual and settled." Friends "should be alert and inventive" (CW2: 121). ${ }^{7}$

In paragraphs fifteen and sixteen Emerson discusses numbers: can more than two persons achieve the high conversation that is the form friendship often takes? What he calls the "law of one to one" is essential for "conversation," and conversation is "the practice and consummation of friendship." The presence of two people is necessary for friendship, but not sufficient, for conversation is a matter of "affinity," not of will. A man reputed to be a great conversationalist, Emerson explains, does not therefore necessarily have "a word [for] his cousin or uncle" (CW2: 122).

European Journal of Pragmatism and American Philosophy, II-2 | 2010 

encounter with one's majestic semblance, is interwoven with themes of distance, reception, patience, and self-reliance. Emerson rewrites a lesson of "The Divinity School Address," where he advises the graduates not to be "too anxious to visit periodically all families and each family in your parish," but to make their occasional visits count: "when you meet one of these men or women, be to them a divine man; [...] let their timid aspirations find in you a friend; let their trampled instincts be genially tempted out in your atmosphere; [...]" (CW1: 90). Now in "Friendship" Emerson writes that we should not "desecrate noble and beautiful souls by intruding on them." The friend is great enough to be revered, but reverence requires distance. "Treat your friend as a spectacle," Emerson advises. "Of course he has merits that are not yours, and that you cannot honor, if you must needs hold him close to your person. Stand aside; give those merits room; let them mount and expand" (CW2: 123). The closeness of friendship requires a certain distance. This closeness is not physical: "You shall not come nearer a man by getting into his house." It is a matter not of will but of what Emerson calls "the uprise of nature in us to the same degree it is in them: then shall we meet as water with water [...]" (CW2: 123-4).

Emerson writes in "Self-Reliance": "do your work and I shall know you." The condition of being known is to do your own work. Friends have more than just knowledge of each other, for they constitute a unity. All this is being said in "Friendship" when Emerson writes: "There must be very two, before there can be very one. Let it be an alliance of two large formidable natures, mutually beheld, mutually feared, before yet they recognize the deep identity which beneath these disparities unites them" (CW 2:123).

In "The Divinity School Address" Emerson contrasts the friendly message of Jesus with the fearful message of the church. Here the friend inspires awe and even fear. Fear of what? Not divine punishment from a wrathful god, but condescension as she rises to new heights. ${ }^{8}$ Friends are equals who spur each other to greater efforts, and greater deeds. Readers of Nietzsche will find anticipations of Thus Spoke Zarathustra's chapter "On the Friend" in the passage from "Friendship" just quoted, and in Emerson's continuation, which goes as follows:

That great defying eye, that scornful beauty of his mien and action, do not pique yourself on reducing, but rather fortify and enhance [...]. Guard him as thy counterpart. Let him be to thee forever a sort of beautiful enemy, untameable, devoutly revered, and not a trivial conveniency to be soon outgrown and cast aside. (CW 2:123-4)

One turns from the friend who no longer does us any good, but not from the friend with whom we beautifully contends. We want to enhance and preserve the friend as beautiful enemy. This friend is to be with us "forever."

In a remarkably similar passage in in Zarathustra, Nietzsche writes:

In a friend one should still honor the enemy. Can you go close to your friend without going over to him?

In a friend one should have one's best enemy. You should be closest to him with your heart when you resist him. [...]

Are you pure air and solitude and bread and medicine for your friend? [...]

Are you a slave? Then you cannot be a friend. Are you a tyrant? Then you cannot have friends. ${ }^{9}$

Nietzsche's tyrant corresponds to Emerson's overly tender or solicitous "friend," who wants us to humor him. We who humor him are his slaves. Friends for both Nietzsche and Emerson preserve and enhance both their own freedom and power and that of their 
friend. As Emerson puts it in the last sentence of his essay, friendship "treats its object as a god, that it may deify both."

Emerson's essay progresses from a diffuse friendship at a distance, to our disappointments with our friends, to the reality of friendship in our lives and its promise of something better than any friendship we have yet achieved. The essay concludes with the repeated warning that much of what we accept as friendship is not the real thing. The concluding tone is set in paragraph twenty-two, which opens in a slightly world-weary fashion: "The higher the style we demand of friendship, of course the less easy to establish it with flesh and blood. We walk alone in the world. Friends, such as we desire, are dreams and fables" (CW 2: 125).

41 In our impatience for companionship, Emerson goes on to say, we settle for friendship of a lower type: for "rash and foolish alliances," "false relations," and "leagues of friendship with cheap persons" (CW 2:125). Reprising the themes of affinity and patience, he counsels his readers not to reach for others who do not belong to them by nature, but to persist in their own paths. Not by will, but only by the attraction of their character will they be able to "draw" to themselves "the first-born of the world."

Echoing earlier passages about the virtue of domestic poverty versus the allure of foreign wealth, Emerson now states:

We go to Europe, or we pursue persons, or we read books in the instinctive faith that these will call it out and reveal us to ourselves. Beggars all. The persons are such as we; the Europe, an old faded garment of dead persons; the books, their ghosts. Let us drop this idolatry. Let us give over this mendicancy. Let us even bid our dearest friends farewell, and defy them, saying, 'Who are you? Unhand me: I will be dependent no more.' (125-6; my italics)

We beg, when we should look at home for what we need. Those from whom we beg are also beggars. Emerson calls our begging practice "idolatry." We mistake another beggar for a god. Idols are made of stone, whereas divinity lies in the power of thought and transition, in, for example, the conversations and confrontations of great friends.

In the essay's penultimate paragraph, Emerson confesses that in his "languid moods" he fails to follow the advice he has given. He occupies himself with "foreign objects" rather than his own development, and settles for the "household joy" and "warm sympathies" that constitute so much of what ordinarily passes for friendship. Yet he also testifies to his turnings from such friendships, a policy of aversion that runs parallel to the relation to books he recommends in "The American Scholar." For while books are a great part of the scholar's education, their true purpose is to inspire the scholar's own thought. This is why "books are for the scholar's idle times" (CW 1: 57). It is not that when you are reading you are not doing anything, but that reading is secondary to your own life. As with books, so with friends:

I do then with my friends as I do with my books. I would have them where I can find them, but I seldom use them. [...] I cannot afford to speak much with my friend. If he is great, he makes me so great that I cannot descend to converse. In the great days, presentiments hover before me in the firmament. [...] Then, though I prize my friends, I cannot afford to talk with them and study their visions, lest I lose my own. (CW 2:126)

As the "Friendship" essay comes to its end, the themes of self-reliance and an extreme if benign separation from others come to the fore. Emerson ends the penultimate paragraph with the thought that he will meet with his friends "as though we met not, and part as though we parted not." He returns to the idea of friendship at a distance in the 
essay's final paragraph: "It has seemed to me lately more possible than I knew, to carry a friendship greatly on one side, without due correspondence on the other." But he immediately undercuts the alleged advantages or virtues of such a friendship when he states: "Yet these things may hardly be said without a sort of treachery to the relation. The essence of friendship is entireness, a total magnanimity and trust" (127). Where does this leave us?

Looking back on the "Friendship" essay, we can see that Emerson offers a range of experiences that constitute friendship: titanic battles between beautiful enemies, conversational brilliance and expansion, a joyful solitude, as if someone has departed rather than arrived, a generalized benevolence toward people in the street to whom one does not speak, the warm sympathies and household joy one shares with a familiar friend, the disappointment of a friend outgrown. The gift of our best friends, Emerson holds, like the gifts of art or literature, is a sense of our own power and prospects.

If I were to register any criticism of Emerson's essay it would be for something he leaves out, namely the death of a friend. No doubt I am particularly sensitive to the issue, as I have lost a dear friend in the past year. It is not as if Emerson knew nothing of such loss, for by the time he published Nature in 1836, he had lost his wife Ellen and his younger brother, Charles. Indeed he brings up the subject of a friend's death in the plaintive and somewhat abrupt end to the first chapter of Nature. After praising nature for her comforts, and recording an ecstatic experience "in snow puddles, at twilight," Emerson ends the chapter as follows:

Nature always wears the colors of the spirit. To a man laboring under a calamity, the heat of his own fire hath sadness in it. Then, there is a kind of contempt of the landscape felt by him who has just lost by death a dear friend. The sky is less grand as it shuts down over less worth in the population. (CW 1: 10-1)

Here the world as a whole loses significance: we are in the domain of what Wittgenstein calls the "world" of "the unhappy man."10

There is another form the loss of a friend takes in our lives, in which it is not the world as a whole that loses its worth or significance, but a part of oneself that is threatened. Emerson sets us in the right direction for appreciating this point when he writes in "Spiritual Laws": "That mood into which a friend can bring us is his dominion over us" (CW 2:84). The word "dominion" means control or lordship, and also the lands or domains of a lord. Putting these senses together we can understand Emerson as saying that our friend allows us to live in a domain that we enter only in the mood into which he can bring us. Now when the friend dies, the mood into which he can bring us, the domain in which we lived together under his authority, dies with him. I think of this as a shrinkage of the self, a loss of that part of us that shows itself only with this friend. ${ }^{11}$ Emerson suggests a different view in "Experience" when he considers the loss of his child and finds, to his surprise and dismay, not a loss of self but a self still intact, though unable to absorb or process the events of its life.

Emerson's skepticism about friendship is part of his critique of the lower, conforming forms that human life mostly takes. His account of friendship shows an intense focus on moral perfection - on our unattained but attainable self, alone and with others -; but an equally intense awareness of what he calls "the plaint of tragedy" that sounds throughout our lives "in regard to persons, to friendship and love." 


\section{NOTES}

1. Emerson uses the term in "Culture" (CW 6: 72, where it is written "mastertones"), but I am following Cavell's adaptation of the term in understanding it name main themes of his work. See Stanley Cavell (2004), "Finding as Founding: Taking Steps in Emerson's ‘Experience'," in Emerson's Transcendental Etudes, Stanford University Press, 117.

2. "The Colors of the Spirit: Emerson and Thoreau on Nature and the Self," "Emerson's Mystical Empiricism," "Paths of Coherence Through Emerson's Philosophy: A Reading of 'Nominalist and Realist'."

3. Textual references are to The Collected Works of Ralph Waldo Emerson (1971-), Cambridge, Harvard University Press.

4. Cavell, "Thinking of Emerson," in Stanley Cavell, Emerson's Transcendental Etudes.

5. Cavell (1979), The Claim of Reason, Oxford University Press, 440.

6. In Aristotle's Nicomachean Ethics, reciprocity is a necessary condition for friendship.

7. This blend of the daily and the inventive matches up nicely with Cavell's descriptions of "remarriage comedy" in Pursuits of Happiness, Cambridge, Harvard University Press.

8. Cf. Emerson's statement that "virtue is Height" (CW2: 40).

9. Portable Nietzsche, 168-9. Nietzsche reread Emerson's essays during the summer before he composed Thus Spoke Zarathustra. See Walter Kaufmann's introduction to The Gay Science, and my "Moral Perfectionism and Democracy in Emerson and Nietzsche," ESQ: A Journal of the American Renaissance, vol. 43, vols. 1-4, 1997, 159-80.

10. Ludwig Wittgenstein (1963), Tractatus Logico-Philosophicus, London, Routledge and Kegan Paul, paragraph 6.43.

11. William James (1983), The Principles of Psychology, Cambridge, Harvard University Press, 280-2.

\section{ABSTRACTS}

Recent conversations with friends and students about Emerson's essay on friendship lead me to suspect that at least some of you will find Emerson's views so strange or radical as not to be about friendship at all. Others will be struck by his anticipations of Nietzsche, whose name I introduce here because like Nietzsche, who read him carefully, Emerson is a genealogist and refashioner of morals. When Emerson criticizes our normal friendships by writing that we mostly "descend to meet," he is recording the possibility, indeed with the word "mostly," the actuality, of something better than what normally passes for friendship. If Emerson finds our friendships disappointing, that is because he thinks that friendship is a high, demanding virtue. In its best actualizations, it carries "the world for me," as he puts it, "to new and noble depths, and enlarge [s] the meaning of all my thoughts." It has the capacity to break down the barriers between people, canceling "the thick walls of individual character, relation, age, sex, circumstance." Friendship is thus a great unifier, a servant of what Emerson calls the "Over-Soul" or "Unity" 
(CW 2:115). But, as Emerson says in his essay on "Montaigne: or the Skeptic," "there are doubts." These doubts about friendships are my main subject in the following essay. 